\title{
Mesoporous silica particles functionalized with newly extracted fish oil (Omeg@Silica) inhibit lung cancer cell growth
}

\author{
Caterina Di Sano, ${ }^{1}$ Claudia D’Anna, ${ }^{* 1}$ Antonino Scurria, ${ }^{2}$ Claudia Lino, ${ }^{2}$ Mario \\ Pagliaro, ${ }^{2}$ Rosaria Ciriminna, ${ }^{* * 2}$ Elisabetta Pace $* * 1$ \\ ${ }^{1}$ Istituto per la Ricerca e l'Innovazione Biomedica, CNR, Via U. La Malfa 153, 90146 \\ Palermo, Italy; ${ }^{2}$ Istituto per lo Studio dei Materiali Nanostrutturati, CNR, Via U. La \\ Malfa 153, 90146 Palermo, Italy
}

\begin{abstract}
Omeg@Silica microparticles consisting of whole fish oil rich in omega-3 lipids, vitamin $\mathrm{D}_{3}$ and zeaxanthin extracted with biobased limonene from anchovy fillet leftovers (AnchoisOil) encapsulated within mesoporous silica particles are highly effective in modulating oxidative stress, mitochondrial damage or in promoting antitumor effects in lung cancer cells. A panel of three different human non-small cell lung cancer (NSCLC) cell lines (A549, Colo 699 and SKMES) was used. Cancer cells were treated with AnchoisOil dispersed in ethanol (10 and 15 $\mu \mathrm{g} / \mathrm{ml})$ or encapsulated in silica, and cell cycle, reactive oxigen species (ROS) and mitochondrial stress (MitoSOX) assessed by flow cytometry. The effects on long-term proliferation (clonogenic assay) were also evaluated. The sub-micron Omeg@Silica microparticles were more effective than fish oil alone in increasing ROS and mitocondrial damage, in altering cell cycle as well as in reducing colony formation ability in the tested lung cancer cell lines. These results suggest that Omeg@Silica mesoporous silica functionalized with whole fish oil has antitumor effects in NSCLC cell lines and support its investigation in lung cancer therapy.
\end{abstract}

Keywords: omega-3, lung cancer, cancer cells, cancer growth, fish oil, PUFA

\footnotetext{
*These Authors equally contributed to the manuscript

**Corresponding authors

Dr E. Pace, MD

Istituto per la Ricerca e l'Innovazione Biomedica, CNR

via U. La Malfa, 153

90146 Palermo (Italy)

E-mail: elisabetta.pace@irib.cnr.it

Dr R. Ciriminna

Istituto per lo Studio dei Materiali Nanostrutturati, CNR

via U. La Malfa, 153

90146 Palermo (Italy)

E-mail: rosaria.ciriminna@cnr.it
} 


\section{Introduction}

Lung cancer is the leading form of cancer worldwide in terms of incidence and death rate, ${ }^{1}$ with non-small cell lung cancer (NSCLC) accounting for $85 \%$ of lung cancer cell types. Despite advances in detection and improvements to standard of care, NSCLC is often diagnosed at an advanced stage and bears poor prognosis. There is a widespread, urgent and global need to implement therapies to improve prognosis of NSCLC.

Regular intake of omega-3 (n-3) marine lipids rich in long-chain polyunsaturated fatty acids (PUFAs) such as docosahexaenoic acid (DHA, C22:6n-3) and eicosapentaenoic acid (EPA, C20:5n-3) is recommended by most world's national and international health authorities for the prevention of many chronic diseases, including cancer. ${ }^{2}$ Following associative epidemiological evidence (changing with time) originating from Dyerberg and Bang discovery of very low incidence of ischemic heartdisease and complete absence of diabetes mellitus in the 1960s Greenland's Inuit population, ${ }^{3}$ detailed physiological, pharmacological and pathophysiological evidence has given clear insights into the benefit from balancing the $n-6$ with $n-3$ lipid molecular mediators in the arachidonic acid cascade. ${ }^{4}$

A plethora of studies have demonstrated that $\omega$-3 PUFAs exert therapeutic role against certain types of cancer, ${ }^{5}$ including lung cancer. ${ }^{6}$ These essential lipids exert inhibitory effects on lung cancer growth by reducing tumor cell proliferation or by increasing cell apoptosis. ${ }^{7}$ In 2014 , Newman and co-workers discovered that in lung carcinoma cell lines, fish oil derived EPA reduces non-small cell lung cancer cellular proliferation through prostaglandin $\mathrm{E} 2\left(\mathrm{PGE}_{2}\right)$ formation by cyclooxygenase-2 (COX-2) enzymes and downregulation of phosphoinositide 3-kinase (PI3K) pathways in NSCLC cells. ${ }^{8}$ Subsequent investigation on the inhibitory role of DHA on NSCLC in vitro and on fat-1 transgenic mice identified in resolvin D1, an eicosanoid metabolite of DHA, the molecule responsible to significantly inhibit lung cancer cell growth and invasion by 
increasing expression of miR-138-5p microRNA precursor, ${ }^{9}$ with concomitant results suggesting that miR-138-5p is indeed a tumor suppressor in NSCLC cells. ${ }^{10}$ Preclinical studies have shown evidence also that omega-3 PUFA metabolites modulate pivotal pathways underlying complications secondary to cancer, up-regulating antiinflammatory lipid mediators such as protectins, maresins, and resolvins. ${ }^{11}$

Unfortunately, a nearly global dietary unbalance between $n-3$ and $n-6$ essential lipids emerged during the $10^{\text {th }}$ and $20^{\text {th }}$ centuries which has led to the present very low to low range of blood EPA + DHA for most of the world's population (6.5 out of 7 billion people in 2015) increasing global risk for chronic disease. ${ }^{12}$

The omega-3 lipid deficit in the diet of most industrialized countries has led to the rapid development of omega-3 dietary supplement industry based on highly refined fish oil, with a significant impact on increasing overfishing across the oceans and in the Mediterranean sea. ${ }^{13}$ These trends originate two urgent needs: to develop sustainable sources of marine lipids, ${ }^{14}$ and to create formulations that may potentiate and expand the physiological activity of formulations based on marine oils, for example avoiding refinement which eliminates from fish oil the lipophilic natural phlorotannins which crucially protect fish oil omega-3 from oxidation and autoxidation. ${ }^{15}$

The present study reports the in vivo anticancer effects of a new formulation (Omeg@Silica) comprised of an integral fish oil (AnchoisOil) rich in omega-3 lipids, vitamin $D_{3}$ and zeaxanthin extracted with biobased limonene from anchovy fillet leftovers ${ }^{16}$ encapsulated within mesoporous silica particles (see Figure S1). ${ }^{17}$ Experiments were carried out testing both the newly sourced AnchoisOil whole fish oil and Omeg@Silica microparticles suspended in aqueous ethanol (FOS) in limiting lung cancer cell growth using a panel of lung cancer cell lines (A549, Colo699 and SK-MES1). 


\section{Materials and Methods}

\section{Extraction of AnchoisOil}

Fish oil was easily obtained from anchovy fillet leftovers kindly donated by an anchovy fillet company based in Sicily (Agostino Recca Conserve Alimentari Srl, Sciacca, Italy) according to a published procedure introduced in $2019 .{ }^{16}$ In detail, $204 \mathrm{~g}$ of frozen anchovy waste in the blender jar of an electric blender was added with a first aliquot of $106 \mathrm{~g}$ of $d$-limonene (Acros Organics, 96\%) refrigerated at $4{ }^{\circ} \mathrm{C}$. After grinding twice for $15 \mathrm{~s}$ each time to mix and homogenize the anchovy leftovers, a semi-solid grey mixture was obtained which was extracted with limonene, an high boling citrus-derived natural solvent with many health-beneficial properties. ${ }^{18}$ An aliquot $(50.7 \mathrm{~g})$ of this mixture was transferred in a glass beaker and added with $51.4 \mathrm{~g}$ of limonene.

The solid-liquid extraction proceeded by magnetically stirring at $700 \mathrm{rpm}$ the mixture kept at room temperature in the beaker closed with an aluminum foil and further sealed with parafilm. After $21 \mathrm{~h}$, the yellow supernatant obtained was transferred to the evaporating balloon of a rotary evaporator (Büchi Rotovapor R-200 equipped with a V-700 vacuum pump and V-850 vacuum controller) to remove the solvent under reduced pressure (40 mbar) at $90{ }^{\circ} \mathrm{C}$. An oily extract weighing $3.0 \mathrm{~g}$ deeply colored in orange (AnchoisOil) remained in the evaporating balloon after limonene evaporation. The oil contains a good amount $(81.5 \mu \mathrm{g} / \mathrm{kg})$ of vitamin D in the form of bioactive isomer vitamin $\mathrm{D}_{3}$ (cholecalciferol), in good agreement with the typical amounts of vitamin $\mathrm{D}_{3}$ found in fish oils. ${ }^{19}$ The limonene solvent almost entirely recovered thanks to the recirculation chiller supporting the rotary evaporator with sufficient cooling to condense the vaporized solvent can be used in a subsequent extraction run. 


\section{Preparation of Omeg@ Silica}

The Omeg@Silica particles used throughout this study are MCM-41 silica particles loaded with $50 \mathrm{wt} \%$ sustainably sourced anchovy fish oil whose highly reproducible synthesis was lately described. ${ }^{17}$ In detail, the synthesis of the MCM-41 material was carried out according to a published template-assisted published sol-gel process. ${ }^{20}$ After dissolving $1 \mathrm{~g}$ of hexadecyltrimethylammonium bromide (CTAB $\geq 99 \%$ pure, Aldrich) and $280 \mathrm{mg}$ of sodium hydroxide (Analyticals, Carlo Erba) in $480 \mathrm{~mL}$ of deionized water, an aliquot $(5.4 \mathrm{~mL})$ of tetraethylorthosilicate (TEOS $\geq 99 \%$ pure, Aldrich) was added dropwise to the solution. The resulting mixture was kept under continuous mechanical stirring $(400 \mathrm{rpm})$ at $80{ }^{\circ} \mathrm{C}$ for $2 \mathrm{~h}$. The solid precipitate was recovered by filtration, washed with abundant deionized water and methanol (99.8\% pure, Aldrich) and dried at $60^{\circ} \mathrm{C}$ for $48 \mathrm{~h}$. The residual surfactant entrapped in the silicate was removed via calcination in air at $550^{\circ} \mathrm{C}$ in a furnace for $6 \mathrm{~h}$.

The resulting MCM-41 mesoporous silica kept in a glass flask under mild mechanical agitation material was added dropwise with the AnchoisOil. Addition of a first $60 \mu \mathrm{L}$ aliquot of fish oil to FMCM-41 (100 mg), was followed by subsequent additions of $20 \mu \mathrm{L}$ aliquots. After $8 \mathrm{~min}$, addition of oil was complete and a material with a $50 \%$ w/w fish oil load was left under agitation for $24 \mathrm{~h}$. Figure S1 displays the resultingOmeg@Silica next to the free AnchoisOil.

The material has a low (0.3) polydispersity index and a large negative (-37.6 $\mathrm{mV}$ ) value of the zeta potential, both important characteristics to develop stable drug delivery applications, ${ }^{21}$ particularly in aqueous phase as the negatively charged particles repel each other preventing aggregation with the dispersion remaining electrostatically stable. The Z-average size (measure of the average size of the particle size distribution resulting by dynamic light scattering) indicates a moderate increase of the average 
particle size from 217 to $269 \mathrm{~nm}$ going from empty mesoporous silica to silica filled with $50 \mathrm{wt} \%$ fish oil.

\section{Preparation of FOS}

The aqueous formulations of different concentrations used throughout this study were obtained by proper dilution of mother suspensions of Omeg@Silica, AnchoisOil and MCM-41 in 10 v/v\% ethanol/ PBS Dulbecco's Phosphate Buffered Saline (Euroclone, Pero, Italy). The Omeg@Silica mother suspension was prepared adding $10.1 \mathrm{mg}$ of material to $10 \mathrm{~mL}$ of $10 \mathrm{v} / \mathrm{v} \%$ ethanol/ PBS solution prepared by adding $1 \mathrm{~mL}$ of ethanol to $9 \mathrm{~mL}$ of PBS. The AnchoisOil and the MCM-41 mother suspensions had a concentration of the single components equivalent to that of Omeg@Silica mother suspension. In particular, $5 \mathrm{mg}$ of AnchoisOil were suspended in $10 \mathrm{~mL}$ of $10 \mathrm{v} / \mathrm{v} \%$ ethanol/ PBS and $5.1 \mathrm{mg}$ of MCM-41 were suspended in $10 \mathrm{~mL}$ of $10 \mathrm{v} / \mathrm{v} \%$ ethanol/ PBS.

\section{Cell cultures}

In this study were used three different human non-small cell lung cancer (NSCLC) cell lines, A549, Colo 699 and SK-MES-1. Eagle's minimum essential medium, supported with $10 \%$ heat-deactivated $\left(56^{\circ} \mathrm{C}, 30 \square \mathrm{min}\right)$ fetal bovine serum (FBS), $1 \%$ nonessential amino acids, $2 \square \mathrm{mM}$ L-glutamine and $0.5 \%$ gentamicin were used for SK-MES-1. RPMI-1640 medium supplemented with heat-deactivated $\left(56^{\circ} \mathrm{C}, 30 \square \mathrm{min}\right) 10 \% \mathrm{FBS}$, streptomycin and penicillin, $1 \%$ nonessential amino acids and $2 \square \mathrm{mM}$ L-glutamine (all from Euroclone) was used for culturing A549 and Colo 699. The cells were maintained in an incubator at $37 \square{ }^{\circ} \mathrm{C}$ with a humidified atmosphere with $5 \% \mathrm{CO}_{2}$ and were maintained as adherent monolayers. The cells were grown grown in polystyrene flasks $25 \mathrm{~cm}^{2}$ (BD Falcon, Franklin Lakes, New Jersey) to $90 \%$ confluence and passaged by trypsin/EDTA. 
Treatment of the cells

Cells were seeded on six-well plates and were cultured to confluence; then the serum was reduced from $10 \%$ to $1 \%$ in the medium and the cells were treated with two different concentrations (5, 10 and $15 \mu \mathrm{g} / \mathrm{ml})$ of AnchoisOildispersed in ethanol, silica sub-micron particles and AnchoisOil encapsulated in silica. At the end of stimulation, cells were collected for further evaluations. At least four replicates were performed for each experiment.

\section{Cell viability/metabolic assay}

To assess the right concentration of the stimuli to add to the culture, we used theCellTiter 96® AQueous One Solution Cell Proliferation Assay(PROMEGA, Madison WI USA), a colorimetric method for determining the number of viable cells in proliferation, cytotoxicity or chemosensitivity assays. Cells were plated in 96-well plates and were treated for $24 \mathrm{~h}$ in triplicate with of AnchoisOildispersed in ethanol (fish oil) $(5,10$ and $15 \mu \mathrm{g} / \mathrm{ml})$, silica sub-micron particles $(5,10$ and $15 \mu \mathrm{g} / \mathrm{ml})$ and AnchoisOil encapsulated in silica (FOS) (5, 10 and $15 \mu \mathrm{g} / \mathrm{ml})$. Then $20 \mathrm{~mL}$ of One Solution reagent contains MTS [3-(4,5-dimethylthiazol-2-yl)-5-(3-carboxymethoxyphenyl)-2-(4-sulfopheyl)2H-tetrazolium]was added to each well, and incubated for 20 $\min$ at $37^{\circ} \mathrm{C}, 5 \% \mathrm{CO} 2$. The absorbance was read at $490 \mathrm{~nm}$ on the Microplate reader WallacVictor2 1420 Multilabel Counter (Perkin Elmer). The results were calculated as the percentage of absorbance with respect to that of the control (untreated cells=NT).

Clonogenic assay 
Clonogenic assay was performed as previously described (Pace E et al ). In six-well plates, a lower layer was prepared using complete medium in $0.5 \%$ agarose. The plates were stored at $4^{\circ} \mathrm{C}$ for 24 hours. The cell lines were stimulated in $1 \%$ FBS medium with the different treatments, as previous described, for 24 hours; then they were harvested and seeded $\left(5 \times 10^{4}\right)$ on the upper layer with $0.3 \%$ agarose prepared with the same medium as the lower layer, and finally incubated for 21 days at $37^{\circ} \mathrm{C}$ in an atmosphere containing $0.5 \% \mathrm{CO}_{2}$. At the end of incubation, colonies were counted under an inverted phase-contrast microscope (Leitz, Wetzlar, Germany). The experiment was conducted in triplicate. Colonies were defined as cell aggregates with at least 40 cells. Results are expressed as percentage of non-treated control (NT). All experiments were performed in triplicate.

\section{Cell Cycle}

The cell lines were stimulated in $1 \%$ FBS medium with the different treatments, as previous described, for 24 hours. After harvesting, the cells were washed twice with icecold PBS and resuspended at $1 \times 10^{6}$ cells $/ \mathrm{ml}$ in hypotonic fluorochrome solution $(0.1 \%$ sodium citrate, $0.03 \%$ Nonidet P-40 and $50 \mu \mathrm{g} / \mathrm{ml}$ propidium iodide) for $30 \mathrm{~min}$ at room temperature in the dark. Then, the cells were acquired and analyzed by flow cytometry. On the basis of DNA content apoptotic cells as M1 (sub-G1 phase), G0/G1 cells as M2, $\mathrm{S}$ cells as M3 and G2/M cells as M4 were identified. Data were expressed as percentage of cells.

\section{Evaluation of mitochondrial stress}

The mitochondrial stress was evaluated by the MitoSOX Kit (Molecular Probes Waltham, MA, USA). The cell lines were stimulated in $1 \%$ FBS medium with the different treatments, as previous described, for 3 hours. After stimulation cells were 
collected and, after the addition of the MitoSOX reagent at the concentration $3 \mu \mathrm{M}$, they were incubated for $15 \mathrm{~min}$ at $37^{\circ} \mathrm{C}$. At the end of the incubation the cells were washed twice in PBS $1 \%$ FBS, followed by flow cytometric analysis. Data were expressed as percentage of cells.

\section{Evaluation of intracellular reactive oxygen species (ROS)}

Intracellular reactive oxygen species (ROS) were measured by the conversion of the non-fluorescent dichlorofluorescein diacetate (DCFH-DA; Sigma) in a highly fluorescent compound, DCF, by monitoring the cellular esterase activity in the presence of peroxides, as previously described (Bruno et al. 2011). The cell lines were stimulated in $1 \%$ FBS medium with the different treatments, as previous described, for 3 hours. After stimulation cells, ROS generation was assessed by the uptake of $1 \mu \mathrm{M}$ DCFH-DA, incubation for $10 \mathrm{~min}$ at room temperature in the dark. At the end of the incubation, the cells were washed twice in PBS and acquired on a FACSCalibur ${ }^{\mathrm{TM}}$ flow cytometer, supported by CellQuest acquisition and data analysis software (Becton Dickinson, Mountain View, CA, USA). Data were expressed as percentage of cells.

\section{Statistics}

Data were expressed as mean \pm SD and analysed by Paired t-test. A p-value of less than 0.05 was considered as statistically significant. 


\section{Results}

\subsection{Effects of fish oil, silica and FOS on cell viability /metabolic activity in}

NSCLC cell lines. Initially, the effects of fish oil $(5,10$ and $15 \mu \mathrm{g} / \mathrm{ml})$, silica $(5,10$ and $15 \mu \mathrm{g} / \mathrm{ml})$ and fish oil in silica (FOS) $(5,10$ and $15 \mu \mathrm{g} / \mathrm{ml})$ on cell viability/metabolic activity after 24 hours were assessed in NSCLC cell lines (A549, Colo699 and SKMES). In A549, silica at 5, 10 and $15 \mu \mathrm{g} / \mathrm{ml}$ and FOS at 10 and $15 \mu \mathrm{g} / \mathrm{ml}$ were able to reduce cell viability /metabolic activity when compared to control and FOS at 10 $\mu \mathrm{g} / \mathrm{ml}$ FOS exerted a significant stronger activity on cell viability/metabolic activity than fish oil (Figure 1 A). In Colo699, only FOS at $10 \mu \mathrm{g} / \mathrm{ml}$ was able to reduce cell viability /metabolic activity when compared to control (Figure 1 B). In SKMES, neither the silica nor oil nor FOS at all the tested concentrations significantly modified cell viability /metabolic activity (Figure $1 \mathrm{C}$ ).

\subsection{Effects of fish oil, silica and FOS on cell cycle events in NSCLC cell}

lines. The effects of fish oil alone (10 and $15 \mu \mathrm{g} / \mathrm{ml})$, silica (10 and $15 \mu \mathrm{g} / \mathrm{ml})$ and FOS (10 and $15 \mu \mathrm{g} / \mathrm{ml}$ ) in cell cycle of the NSCLC cell lines (A549, Colo699 and SKMES) were tested. In A549, fish oil alone at both the tested concentrations was able to significantly reduce $\mathrm{M} 3$ (fish oil at 10 and at $15 \mu \mathrm{g} / \mathrm{ml}$ vs. NT: $\mathrm{p}=0.0129$ and $\mathrm{p}=$ $\mathrm{p}=0.02$ ) without any effects on M1, M2 or M4. Silica at $10 \mu \mathrm{g} / \mathrm{ml}$ but not at $15 \mu \mathrm{g} / \mathrm{ml}$ was able to increase M1 (silica at $10 \mu \mathrm{g} / \mathrm{ml} v s$. NT: $\mathrm{p}=0.014$ ) and Silica at $15 \mu \mathrm{g} / \mathrm{ml}$ was able to significantly reduce M3 (silica $15 \mu \mathrm{g} / \mathrm{ml} v s$. NT: $\mathrm{p}=0.006$ ).

FOS at $10 \mu \mathrm{g} / \mathrm{ml}$ was able to significantly increase M1 (FOS at $10 \mu \mathrm{g} / \mathrm{ml} v s$. NT: $\mathrm{p}=0.019$ ) without any effects on M2, M3 or M4. This effect was significantly higher than the effects mediated by fish oil alone at the same concentration (FOS at $10 \mu \mathrm{g} / \mathrm{ml}$ vs. fish oil at $10 \mu \mathrm{g} / \mathrm{ml} \mathrm{p}=0.014$ ) (Figures 2A-2B). In Colo699, fish oil alone at both the tested concentrations was able to significantly reduce M3 ( $a$ : fish oil at 10 and $15 \mu \mathrm{g} / \mathrm{ml}$ 
vs. NT: $\mathrm{p}=0.0012$ and $\mathrm{p}=0.005$ ) without any effects on M1 and M2. Fish oil at $10 \mu \mathrm{g} / \mathrm{ml}$ significantly reduced M4 (fish oil at $10 \mu \mathrm{g} / \mathrm{ml}$ vs NT: $\mathrm{p}=0.007$.

Periodic mesoporous silica at $15 \mu \mathrm{g} / \mathrm{ml}$ significantly reduced M4 (b: silica at $15 \mu \mathrm{g} / \mathrm{ml} v s . \mathrm{NT}: \mathrm{p}<0.003)$ without any effects on M1, M2 and M3.

FOS at $10 \mu \mathrm{g} / \mathrm{ml}$ was able to significantly increase M1 (FOS at $10 \mu \mathrm{g} / \mathrm{ml}$ vs NT: $\mathrm{p}=0.008$ ) and this effect was significantly higher than the effects mediated by fish oil alone at the same concentration ( $c$ : FOS at $10 \mu \mathrm{g} / \mathrm{ml}$ vs fish oil at $10 \mu \mathrm{g} / \mathrm{ml} \mathrm{p}=0.037$ ). FOS at $10 \mu \mathrm{g} / \mathrm{ml}$ significantly reduced M4 (FOS at $10 \mu \mathrm{g} / \mathrm{ml}$ vs NT: $\mathrm{p}=0.025$ ) without any effects on M2 and M3 (Figures 3A-3B).

In SKMES: fish oil alone at both the tested concentrations was able to significantly reduce M3 ( $a$ : fish oil at 10 and at $15 \mu \mathrm{g} / \mathrm{ml} v s$. NT: $\mathrm{p}=0.005$ and $\mathrm{p}=0.001$ ) and M4 (fish oil at 10 and at $15 \mu \mathrm{g} / \mathrm{ml}$ vs NT: $\mathrm{p}=0.02$ and $\mathrm{p}=0.003$ ) while only at 10 $\mu \mathrm{g} / \mathrm{ml}$ was able to increase M2 (fish oil at $10 \mu \mathrm{g} / \mathrm{ml} v s$. NT: $\mathrm{p}=0.03$ ); silica at $15 \mu \mathrm{g} / \mathrm{ml}$ significantly increased M2 and reduced M3 ( $b$ : silica at $15 \mu \mathrm{g} / \mathrm{ml} v s$. NT: $\mathrm{p}=0.002)$; FOS at $10 \mu \mathrm{g} / \mathrm{ml}$ significantly increased M2 (FOS at $10 \mu \mathrm{g} / \mathrm{ml} v s$. NT: $\mathrm{p}=0.01$ ) and reduced M3 (FOS at $10 \mu \mathrm{g} / \mathrm{ml}$ vs. NT: $\mathrm{p}=0.0009$ ) while FOS at both the tested concentrations significantly reduced M4 ( $c$ : FOS at 10 and at $15 \mu \mathrm{g} / \mathrm{ml} v s$. NT: $\mathrm{p}=0.03$ and $\mathrm{p}=0.03$ ) (Figures 4A-4B).

\subsection{Effects of fish oil, silica and FOS on colony formation ability in NSCLC} cell lines. In A549 (Figure 5A), in Colo699 (Figure 5B) and in SKMES (Figure 5C) only FOS at $10 \mu \mathrm{g} / \mathrm{ml}$ significantly reduced colony number when compared to untreated cells or to the other experimental conditions, including fish oil alone at the same concentration.

\subsection{Effects of fish oil, silica and FOS on mitochondrial stress in NSCLC cell}

lines. Mitochondria play an essential role in the survival and maintenance of cancer 
cells and have been considered a target for anticancer agents. ${ }^{22}$ In A549, mitochondrial stress was increased upon exposure to fish oil, to silica and to FOS at both the tested concentrations. Both concentrations of FOS exerted a significant stronger activity on mitochondrial stress than fish oil or silica alone (Figures 6A-6B). In Colo699, mitochondrial stress was increased upon exposure to silica at $15 \mu \mathrm{g} / \mathrm{ml}$ and to FOS at both the tested concentrations. Both concentrations of FOS exerted a significant stronger activity on mitochondrial stress than fish oil or silica alone at both the tested concentrations (Figures 7A-7B).

In SKMES, mitochondrial stress was increased upon exposure to fish oil at 10 $\mu \mathrm{g} / \mathrm{ml}$ and to silica and to FOS at both the tested concentrations. Both concentrations of FOS exerted a significant stronger activity on mitochondrial stress than fish oil alone at both the tested concentrations (Figures 8A-8B).

\subsection{Effects of fish oil, silica and FOS on ROS content in NSCLC cell lines.}

Upregulation of mitochondrial superoxide leads to increased intracellular ROS levels. ${ }^{23}$ In A549, it was observed a significant increase in ROS levels upon exposure to fish oil at both the tested concentrations, to silica $15 \mu \mathrm{g} / \mathrm{ml}$ and to both concentrations of FOS. Both concentrations of FOS exerted a significant stronger activity on ROS than fish oil alone at the same concentration (Figures 9A-9B).

In Colo699, it was observed a significant increase in ROS levels upon exposure to fish oil and to FOS at both the tested concentrations. FOS at $10 \mu \mathrm{g} / \mathrm{ml}$ exerted a significant stronger activity on ROS than fish oil alone at the same concentration (Figures 10A-10B). In SKMES, it was observed a significant increase in ROS levels upon exposure to FOS at $10 \mu \mathrm{g} / \mathrm{ml}$ and FOS at $10 \mu \mathrm{g} / \mathrm{ml}$ exerted a significant stronger activity on ROS than fish oil or silica alone at the same concentration (Figures 11A11B). 


\section{Discussion}

The use of whole fish oil alone or encapsulated in silica particles in the present study represents an usual approach since the majority of the in vitro studies on the anti-cancer effects of omega-3 PUFAs assess the effects of the two major single EPA and DHA components in non esterified, acid form. ${ }^{24}$

The toxic effects of specific compounds on cancer cells can be evaluated by anlyzing early events looking at cell cycle alterations or late events assessing colony forming ability. Data reported herein demonstrate that FOS altered cell cycle phases in all the tested cell lines. At ultralow concentration of $10 \mu \mathrm{g} / \mathrm{ml} \mathrm{FOS} \mathrm{was} \mathrm{able} \mathrm{to} \mathrm{increase}$ the number of apoptotic cells (identified as cell with reduced DNA content) in adenocarcinoma cell lines and to reduce colony forming ability in all the tested cancer cell lines. FOS was more effective than AnchoisOil fish oil alone at the same concentration.

Single components of fish oil, EPA and DHA, are able to induce toxic effects (cell apoptosis o reduced cell proliferation) on lung cancer cells, but at higher concentrations ranging from 50 to $75 \mu \mathrm{g} / \mathrm{ml} .^{25}$ These findings further support the effectiveness of this new silica-based formulation comprised of whole fish oil heterogenized in mesoporous silica. Hovewer, FOS at both tested concentrations does not increase cell apoptosis but reduces colony forming ability in squamous carcinoma cell line (SKMES). Taken togeheter, these data suggest that adenocarcinoma cells arising from distal airway epithelium are more sensitive in terms of early events (cell apoptosis) than cancer epithelial cells from the proximal airways. Future studies are needed to validate further higher concentrations of FOS for inducing early cell apoptosis also in lung squamous carcinoma.

With regard to late anti-cancer events, FOS reduced the colony forming ability in all the tested cancer cells. This could be related to the alteration on arachidonic acid 
(AA) metabolism. Indeed, the increased concentration of omega-3 PUFAs in cancer cells, associated with a statistically significant reduction in AA concentrations, suppresses AA-derived eicosanoid (PGs) biosynthesis thereby decreasing $\mathrm{PGE}_{2}$ concentration. ${ }^{26}$ As mentioned above, a further mechanism employed by omega-3 lipids to decrease $\mathrm{PGE}_{2}$ levels is linked to an inhibitory effect on COX-2, the cyclooxygenase enzyme responsible for the $\mathrm{PGE}_{2}$ synthesis. ${ }^{27,28}$ Prostaglandin E2 promotes tumor growth my multiple autocrine and paracrine mechanisms that increase cell proliferation and tissue invasion reducing cancer cell apoptosis and the efficiency of anti-cancer immune responses. $^{29}$ In this context, it has been demonstrated that PGE contained in exudative pleural effusions from lung adenocarcinoma patients, is able to increase the colony forming ability of adenocarcinoma cell line (Colo699). ${ }^{30}$

Moreover, compounds capable of further increasing the oxidative stress within cancer cells have anticancer potential due to their ability to induce cell apoptosis, inhibiting cell proliferation and tissue invasiveness. Exerting a crucial role in ATP production and biosynthesis of macromolecules, mitochondria exert a relevant role in increasing intracellular ROS production. The mitochondrial metabolism is crucial for tumor proliferation, tumor survival, and metastasis. ${ }^{22}$ Compounds exerting antiproliferative and apoptotic activities in A549 human lung cancer alter mitochondrial function. ${ }^{31}$ Defects in mitochondrial ATP synthesis and mitochondrial membrane potential increase superoxide production thus leading to cell apoptosis. Multiple mechanisms may account for increased mitochondrial superoxide production. In this regard, inhibition of PIM kinases caused excessive mitochondrial fission and significant upregulation of mitochondrial superoxide. ${ }^{32}$

In addition, Bcl-2 levels are essential to mantain mitochondria integrity and preventing cell apoptosis. DHA downregulates Bcl-2 and upregulates Bax. ${ }^{33}$ When Bax transfers to the cell membrane, and binds to Bcl-2, it alters mitochodrial membrane 
potential and leads to increased superoxide production and to the release of cytochrome c, inducing cell apoptosis. Since FOS increase mitochondrial superoxide production and induce cell apoptosis, it is also conceivable that FOS could promote the interaction between Bax and Bcl-2. Moreover, fish oil can directly iincrease ROS levels. In this regard, it has been demonstrated that DHA increases ROS production by downregulating catalase. ${ }^{32}$

We ascribe the enhanced anticarcinogenic activity of Omeg@Silica in comparison to whole fish oil alone, to the hydrophilic nature of the embedding silica matrix and to large inner mesoporosity which allows to encapsulate within the hexagonal channels of periodic mesoporous silica an high load of bioactive AnchoisOil. Cancer cells are known to be acidic and are known to efficiently take up mesoporous silica nanoparticles functionalized with hydrophobic cancer drugs into the acidic organelles. ${ }^{34}$ Delivery of the omega-3 lipid molecules into the cancer cells leads to growth inhibition and cell impairment on all lung cancer-cell lines examined. Yet, mesoporous $\mathrm{SiO}_{2}$ submicron particles are not toxic to human cells and end up preferentially localized in (acidic) lysosomes of cancer cells, ${ }^{35}$ which makes them ideally suited biocompatibile carriers for a host of hydrophobic anticancer drugs.

\section{Conclusions}

In this study we report the discovery of the high anticancer activity of a new material comprised of whole fish oil (AnchoisOil) extracted from anchovy fillet leftovers with biobased limonene sequestered within the inner mesoporosity of periodic mesoporous MCM-41 silica submicron particles. Tested in vitro on lung adenocarcinoma A549 and Colo699 cells, an aqueous formulation of these Omeg@Silica submicron particles in aqueous ethanol (FOS) is significantly more active than the fish oil alone in terms of effects on cell apoptosis, long term proliferation and mitochondrial superoxide ROS 
production. Less pronounced effects were observed when lung squamous cancer cells were treated with both fish oil and FOS.

Several aspects support further pre-clinical investigation of this new functional material in the treatment of lung cancer. First, the whole oil rich in omega-3 lipids, vitamin $\mathrm{D}_{3}$, zeaxanthin is directly obtained in natural form and at low cost from a freely available and abundant fishery by-product using a biobased and health-beneficial solvent (limonene) widely used in the food industry. ${ }^{10}$ No refinement of the resulting fish oil is needed to obtain the omega-3 lipids in diethylester form as it happens with most commercial omega-3 supplements. ${ }^{14}$

Second, the encapsulant material comprised of low polydisperse, submicron $(269 \mathrm{~nm})$ silica particles of large negative zeta potential $(-32 \mathrm{mV})$ devoid of toxicity for healthy tissues ${ }^{34,35}$ is ideally suited to deliver the hydrophobic molecules comprising the AnchoisOil. These include EPA and DHA in natural (and highly bioavailable) ${ }^{36}$ form (DHA in position 2- and EPA in positions 1 and 3 of the triglyceride molecules) form as well as vitamin $\mathrm{D}_{3}$ and natural zeaxanthin. Both cholecalciferol ${ }^{37}$ and zeaxanthin ${ }^{38}$ are known to exert anticancer activity. This study, in conclusion, shows evidence that FOS exert anti-tumor effects on NSCLC affecting mitochondrial function and cell growth ability. Further studies to further characterize the molecular mechanisms originating the anti-cancer activity of FOS are needed to support the use of this new formulation in the therapy of lung cancer. 


\section{Author ORCID}

Caterina Di Sano: 0000-0003-3904-3465

Claudia D’Anna: 0000-0001-6673-1701

Antonino Scurria: 0000-0001-5624-6833

Claudia Lino: 0000-0002-8724-7772

Mario Pagliaro: 0000-0002-5096-329X

Rosaria Ciriminna: 0000-0001-6596-1572

Elisabetta Pace: 0000-0003-1141-9010

\section{Author Contributions}

Caterina Di Sano and Claudia D'Anna conducted the largest number of experiments, participated in the interpretation of the data. contributed to write the manuscript and declare that they take the responsibility for the accuracy of the data analysis. Antonino Scurria and Claudia Lino extracted fish oil, synthesized mesoporous silica particles and incorporated fish oil in mesoporous silica affording the Omeg@Silica material. Mario Pagliaro revised the original manuscript and designed the Omeg@Silica structural investigation. Rosaria Ciriminna conceived the Omeg@ Silica material and participated in the interpretation of the data. Elisabetta Pace designed the study, performed the statistical analysis of the data, contributed to the interpretation of the data, contributed to write the manuscript and declares that she has had access to and takes responsibility for the integrity of the data. All authors approved the final version of the manuscript.

\section{Conflict of interest}

All the authors declare that there is no conflict of interest regarding the publication of this paper.

\section{Funding}

No specific funding was received supporting this study. Researchers used existing laboratory equipment and resources available to their Italy's National Research Council (CNR) Institutes based in Palermo, Sicily.

\section{Data availability statement}

Data used to support the findings of this study are included in the present article.

\section{Acknowledgments}

We thank Agostino Recca Conserve Alimentari Srl (Sciacca, Italy) for kindly providing leftovers of anchovy fillets. 


\section{Main abbreviations}

Non-small cell lung cancer (NSCLC)

Squamous carcinoma cell line (SKMES)

Polyunsaturated fatty acids (PUFAs)

Docosahexaenoic acid (DHA)

Eicosapentaenoic acid (EPA)

Fish oil encapsulated in mesoporous silica formulated in acqueous ethanol (FOS)

Dichlorofluorescein diacetate (DCFH-DA)

Cetyltrimethylammonium bromide (CTAB)

Arachidonic acid (AA)

Reactive oxygen species (ROS)

Prostaglandin E2 $\left(\mathrm{PGE}_{2}\right)$

Cyclooxygenase-2 (COX-2)

Non-treated (NT) 


\section{Figure Legends}

Figure 1. Effect of fish oil, silica and FOS on cell viability /metabolic activity in NSCLC cell lines. NSCLC cell lines, A549 (A), Colo699 (B), and SKMES (C) were cultured for 24 hours with fish oil $(5,10$ and $15 \mu \mathrm{g} / \mathrm{ml})$, silica $(5,10$ and $15 \mu \mathrm{g} / \mathrm{ml})$ and fish oil in silica (FOS) $(5,10$ and $15 \mu \mathrm{g} / \mathrm{ml})$ and cell viability/metabolic activity was assessed by MTS. Data are expressed as $\%$ of NT and represent mean \pm S.D. $(n=3)$. $\mathrm{p}<0.05$

Figure 2. Effect of fish oil, silica and FOS on cell cycle events in A549 cells. A549 were cultured for 24 hours with fish oil (10 and $15 \mu \mathrm{g} / \mathrm{ml})$, silica (10 and $15 \mu \mathrm{g} / \mathrm{ml})$ and fish oil in silica (FOS) (10 and $15 \mu \mathrm{g} / \mathrm{ml}$ ) and cell cycle was assessed by flow cytometry. A. Data are expressed as percentage of cells (mean $\pm \mathrm{SD}$ ). ${ }^{*} \mathrm{p}<0.05$. B. Representative histograms were shown.

Figure 3. Effect of fish oil, silica and FOS on cell cycle events in Colo699. Colo699 were cultured for 24 hours with fish oil $(10$ and $15 \mu \mathrm{g} / \mathrm{ml})$, silica $(10$ and $15 \mu \mathrm{g} / \mathrm{ml})$ and fish oil in silica (FOS) (10 and $15 \mu \mathrm{g} / \mathrm{ml}$ ) and cell cycle was assessed by flow cytometry. A. Data expressed as percentage of cells (mean $\pm \mathrm{SD}$ ). ${ }^{*} \mathrm{p}<0.05$. B. Representative histograms are shown.

Figure 4. Effect of fish oil, silica and FOS on cell cycle events in SKMES. SKMES were cultured for 24 hours with fish oil (10 and $15 \mu \mathrm{g} / \mathrm{ml})$, silica (10 and $15 \mu \mathrm{g} / \mathrm{ml})$ and fish oil in silica (FOS) (10 and $15 \mu \mathrm{g} / \mathrm{ml}$ ) and cell cycle was assessed by flow cytometry. A. Data expressed as percentage of cells (mean $\pm \mathrm{SD}$ ). ${ }^{*} \mathrm{p}<0.05$. B. Representative histograms are shown.

Figure 5. Effect of fish oil, silica and FOS on colony formation ability in NSCLC cell lines. NSCLC cell lines, A549 (A), Colo699 (B), and SKMES (C) were cultured for 24 hours with fish oil (10 and $15 \mu \mathrm{g} / \mathrm{ml})$, silica $(10$ and $15 \mu \mathrm{g} / \mathrm{ml})$ and fish oil in silica (FOS) (10 and $15 \mu \mathrm{g} / \mathrm{ml}$ )and colony forming ability was assessed by clonogenic assay. Data expressed as percentage of control (NT) (mean \pm SD). ${ }^{*} \mathrm{p}<0.05$.

Figure 6. Effect of fish oil, silica and FOS on mitochondrial superoxide production in A549 cells. A549 cells were cultured for 24 hours with fish oil (10 and $15 \mu \mathrm{g} / \mathrm{ml})$, silica (10 and $15 \mu \mathrm{g} / \mathrm{ml}$ ) and fish oil in silica (FOS) $(10$ and $15 \mu \mathrm{g} / \mathrm{ml}$ ) and mitochondrial superoxide production was assessed using MITOSOX by flow cytometry. Data expressed as percentage of positive cells (mean \pm SD). ${ }^{*} p<0.05$. B. Representative dot plots are shown.

Figure 7. Effect of fish oil, silica and FOS on mitochondrial superoxide production in Colo699 cells. Colo699 cells were cultured for 24 hours with fish oil (10 and 15 $\mu \mathrm{g} / \mathrm{ml}$ ), silica (10 and $15 \mu \mathrm{g} / \mathrm{ml})$ and fish oil in silica (FOS) $(10$ and $15 \mu \mathrm{g} / \mathrm{ml})$ and mitochondrial superoxide production was assessed using MITOSOX by flow cytometry. Data expressed as percentage of positive cells (mean \pm SD). ${ }^{*} \mathrm{p}<0.05$. B. Representative dot plots are shown.

Figure 8. Effect of fish oil, silica and FOS on mitochondrial superoxide production in SKMES cells. SKMES cells were cultured for 24 hours with fish oil (10 and 15 $\mu \mathrm{g} / \mathrm{ml}$ ), silica (10 and $15 \mu \mathrm{g} / \mathrm{ml})$ and fish oil in silica (FOS) $(10$ and $15 \mu \mathrm{g} / \mathrm{ml})$ and mitochondrial superoxide production was assessed using MITOSOX by flow cytometry. 
Data expressed as percentage of positive cells (mean \pm SD). ${ }^{*} \mathrm{p}<0.05$. B. Representative dot plots are shown.

Figure 9. Effects of fish oil, silica and FOS on ROS production in A549 cells. A549 were cultured for 24 hours with fish oil (10 and $15 \mu \mathrm{g} / \mathrm{ml})$, silica (10 and $15 \mu \mathrm{g} / \mathrm{ml})$ and fish oil in silica (FOS) (10 and $15 \mu \mathrm{g} / \mathrm{ml})$ and ROS production was assessed using DCFH-DA by flow cytometry. Data are expressed as percentage of positive cells $\left(\right.$ mean \pm SD). ${ }^{*} \mathrm{p}<0.05$. B. Representative dot plots are shown.

Figure 10. Effects of fish oil, silica and FOS on ROS production in Colo699 cells. Colo699 were cultured for 24 hours with fish oil (10 and $15 \mu \mathrm{g} / \mathrm{ml})$, silica (10 and 15 $\mu \mathrm{g} / \mathrm{ml})$ and fish oil in silica (FOS) (10 and $15 \mu \mathrm{g} / \mathrm{ml})$ and ROS production was assessed using DCFH-DA by flow cytometry. Data expressed as percentage of positive cells $\left(\right.$ mean \pm SD). ${ }^{*} \mathrm{p}<0.05$. B. Representative dot plots are shown.

Figure 11. Effects of fish oil, silica and FOS on ROS production in SKMES cells. SKMES were cultured for 24 hours with fish oil (10 and $15 \mu \mathrm{g} / \mathrm{ml})$, silica (10 and 15 $\mu \mathrm{g} / \mathrm{ml})$ and fish oil in silica (FOS) (10 and $15 \mu \mathrm{g} / \mathrm{ml})$ and ROS production was assessed using DCFH-DA by flow cytometry. Data expressed as percentage of positive cells $($ mean $\pm S D) .{ }^{*} \mathrm{p}<0.05$. B. Representative dot plots are shown. 


\section{References}

1. A. Jemal, R. Siegel, E. Ward, Y. Hao, J. Xu, M.J. Thun, Cancer statistics, CA Cancer J. Clin. 2009, 59, 225-249. https://doi.org/10.3322/caac.20006

2. A. P. Simopoulos, Omega-6/Omega-3 Essential Fatty Acid Ratio and Chronic Diseases, Food Rev. Int. 2006, 20, 77-90. https://doi.org/10.1081/FRI-120028831

3. H.O. Bang, J. Dyerberg, A.B. Nielsen, Plasma lipid and lipoprotein pattern in Greenlandic West-coast Eskimos, Lancet 1971, 1, 1143-1145. https://doi.org/10.1016/s0140-6736(71)91658-8

4. B. Lands, Omega-3 PUFAs Lower the Propensity for Arachidonic Acid Cascade Overreactions, BioMed Res. Int. 2015, 2015, 285135. http://dx.doi.org/10.1155/2015/285135

5. S.C. Larsson, M. Kumlin, M. Ingelman-Sundberg, A. Wolk, Dietary long-chain n-3 fatty acids for the prevention of cancer: a review of potential mechanisms, Am. J. Clin. Nutr. 2004, 79, 935-945. https://doi.org/10.1093/ajcn/79.6.935

6. O. M. Vega, S. Abkenari, Z. Tong, A. Tedman, S. Huerta-Yepez, Omega-3 Polyunsaturated Fatty Acids and Lung Cancer: nutrition or Pharmacology?, Nutr. Cancer 2021, 73, 541-561. https://doi.org/10.1080/01635581.2020.1761408

7. M. Wendel, A.R. Heller, Anticancer actions of omega-3 fatty acids - current state and future perspectives, Anticancer Agents Med. Chem. 2009, 9, 457-470. https://doi.org/10.2174/1871520610909040457

8. P. Yang, C. Cartwright, J. Ding, E. Felix, Y. Pan, J. Pang, P. Rhea, K. Block, S. M. Fischer, R. A. Newman, Anticancer Activity of Fish Oils against Human Lung Cancer Is Associated with Changes in Formation of $\mathrm{PGE}_{2}$ and $\mathrm{PGE}_{3}$ and Alteration of Akt Phosphorylation, Mol. Carcinog. 2014, 53, 566-577. https://dx.doi.org/10.1002/mc.22008

9. X. Bai, J. Shao, S. Zhou, Z. Zhao, F. Li, R. Xiang, A. Z. Zhao, J. Pan, Inhibition of lung cancer growth and metastasis by DHA and its metabolite, RvD1, through miR138-5p/FOXC1 pathway J. Exp. Clin. Cancer Res. 2019, 38, 479. https://doi.org/10.1186/s13046-019-1478-3

10. S. Xing, Q. Xu, X. Fan, S. Wu, F. Tian, Downregulation of miR-138-5p promotes non-small cell lung cancer progression by regulating CDK8, Mol. Med. Rep. 2019, 20, 5272-5278. https://doi.org/10.3892/mmr.2019.10741

11. R.D.S. Freitas, M.M. Campos, Protective Effects of Omega-3 Fatty Acids in $\begin{array}{lllll}\text { Cancer-Related } \quad \text { Complications, } & \text { Nutrients } & \text { 2019, } & \text { 11, } & 945 .\end{array}$ https://doi.org/10.3390/nu11050945

12. K.D. Stark, M.E. Van Elswyk, M.R. Higgins, C.A. Weatherford, N. Salem, Global survey of the omega-3 fatty acids, docosahexaenoic acid and eicosapentaenoic acid in the blood stream of healthy adults, Progr. Lipid Res. 2016, 63, 132-152. https://doi.org/10.1016/j.plipres.2016.05.001

13. P.D. Nichols, J. Petrie, S. Singh, Long-Chain Omega-3 Oils-An Update on Sustainable Sources, Nutrients 2010, 2, 572-585. https://doi.org/10.3390/nu2060572

14. R. Ciriminna, F. Meneguzzo, R. Delisi, M. Pagliaro, Enhancing and improving the extraction of omega-3 from fish oil, Sustainable Chem. Pharm. 2017, 5, 54-59. https://doi.org/10.1016/j.scp.2017.03.001

15. P. R Clayton, S. Ladi, From alga to omega; have we reached peak (fish) oil?, J. $R$. Soc. Med. 2015, 108, 351-357. https://dx.doi.org/10.1177/0141076815599673

16. R. Ciriminna, A. Scurria, G. Avellone, M. Pagliaro, A Circular Economy Approach to Fish Oil Extraction, ChemistrySelect 2019, 4, 5106-5109. https://doi.org/10.1002/slct.201900851

17. R. Ciriminna, C. Lino, M.Pagliaro, Omeg@ Silica: In-Silica Stabilization of Sustainable Fish Oil, ChemistryOpen 2021, https://doi.org/10.1002/open.202100038 
18. R. Ciriminna, M. Lomelli, P. Demma Carà, J. Lopez-Sanchez, M. Pagliaro, Limonene: A Versatile Chemical of the Bioeconomy, Chem. Commun. 2014, 50, 1528815296. http://dx.doi.org/10.1039/c4cc06147k

19. A. Scurria, C. Lino, R. Pitonzo, M. Pagliaro, G. Avellone, R. Ciriminna, Vitamin D3 in Fish Oil Extracted with Limonene from Anchovy Leftovers, Chem. Data Collect. 2020, 25, 100311. https://doi.org/10.1016/j.cdc.2019.100311

20. S. A. Jadhav, I. Miletto, V. Brunella, D. Scalarone, G. Berlier, Porous Silica Particles: Synthesis, Physicochemical Characterization and Evaluation of Suspension Stability, Phys. Chem. Ind. J. 2017, 12, 102.

21. M. Danaei, M. Dehghankhold, S. Ataei, F. Hasanzadeh Davarani, R. Javanmard, A. Dokhani, S. Khorasani, M. R. Mozafari, Impact of Particle Size and Polydispersity Index on the Clinical Applications of Lipidic Nanocarrier Systems, Pharmaceutics 2018, 10, 57. https://doi.org/10.3390/pharmaceutics10020057

22. P. Ghosh, C. Vidal, S. Dey, L. Zhang, Mitochondria Targeting as an Effective Strategy for Cancer Therapy, Int. J. Mol. Sci. 2020, 21, 3363. https://doi.org/10.3390/ijms21093363

23. D.B. Zorov, M. Juhaszova, S.J. Sollott, Mitochondrial reactive oxygen species (ROS) and ROS-induced ROS release, Physiol. Rev. 2014, 94, 909-950. https://doi.org/10.1152/physrev.00026.2013

24. D. D'Eliseo, F. Velotti, Omega-3 Fatty Acids and Cancer Cell Cytotoxicity: Implications for Multi-Targeted Cancer Therapy, J. Clin. Med. 2016, 5, 15. https://doi.org/10.3390/jcm5020015

25. W. Ren, J. Wu, X, Wang, Z, Feng, X, Shang, Z, Peng, DHA increases the antitumor effect of gefitinib on non-small cell lung cancer with EGFR mutations in vitro, Int. J. Clin. Exp. Med. 2017, 10, 7647-7657.

26. K. Kinoshita, M. Noguchi, and M. Tanaka, Effects of linoleic acid, icosapentaenoic acid, and docosahexaenoic acid on the growth and metastasis of MM48 mammary tumor transplants in mice, Int. J. Oncol. 1996, 8, 575-581. https://doi.org/10.3892/ijo.8.3.575

27. J.Y. Lee, Plakidas A, Lee WH, Heikkinen A, Chanmugam P, G. Bray, Differential modulation of Toll-like receptors by fatty acids: preferential inhibition by $n-3$ polyunsaturated fatty acids, J. Lipid Res. 2003, 44, 479-486. https://doi.org/10.1194/jlr.m200361-jlr200

28. Q. Jia, Zhou HR, Bennink M, J.J. Pestka, Docosahexaenoic acid attenuates mycotoxin-induced immunoglobulin a nephropathy, interleukin-6 transcription, and mitogen-activated protein kinase phosphorylation in mice, J. Nutr. 2004, 134, 33433349. https://doi.org/10.1093/jn/134.12.3343

29. F. Finetti, Travelli, C.; Ercoli, J.; Colombo, G.; Buoso, E.; L. Trabalzini, Prostaglandin E2 and Cancer: Insight into Tumor Progression and Immunity, Biology 2020, 9, 434. https://doi.org/10.3390/biology9120434

30. E. Pace, L. Siena, Ferraro, M., Profita, M., Mondello, P., Chiappara, G., M. Montalbano, A. Giarratano, G. Bonsignore, M. Gjomarkaj, Role of prostaglandin E2 in the invasiveness, growth and protection of cancer cells in malignant pleuritis, Eur. $J$. Canc. 2006, 42, 2382-2389. https://doi.org/10.3390/biology9120434

31. C. Cao, Ling Zhu, Ye Chen, Cheng-Hui Wang, Jian-Zhong Shen Tu, Yun-Liang Zheng, Physalin B induces G2/M cell cycle arrest and apoptosis in A549 human nonsmall-cell lung cancer cells by altering mitochondrial function, Anticancer Drugs 2019, 30, 128-137. https://doi.org/10.1097/cad.0000000000000701

32. S.S. Chauhan, Rachel K Toth, Corbin C Jensen, Andrea L Casillas, David F Kashatus, Noel A Warfel, PIM kinases alter mitochondrial dynamics and 
chemosensitivity in lung cancer, Oncogene 2020, 39, 2597-2611. https://doi.org/10.1038/s41388-020-1168-9

33. Y. Yin, C. Sui, F. Meng, The omega-3 polyunsaturated fatty acid docosahexaenoic acid inhibits proliferation and progression of non-small cell lung cancer cells through the reactive oxygen species-mediated inactivation of the PI3K /Akt pathway, Lipids Health Dis. 2017, 16, 87. https://doi.org/10.1186/s12944-017-0474-X

34. J. Lu, M. Liong, J. Zink, F. Tamanoi, Mesoporous Silica Nanoparticles as a Delivery System for Hydrophobic Anticancer Drugs, Small 2007, 3, 1341-1346. https://doi.org/10.1002/smll.200700005

35. M. Al-Rawi, S. Diabaté, C. Weiss, Uptake and intracellular localization of submicron and nano-sized SiO2 particles in HeLa cells, Arch. Toxicol. 2011, 85, 813826. https://doi.org/10.1007/s00204-010-0642-5

36. A. Wakil, M. Mir, D. D Mellor, S. F Mellor, S. L Atkin, The bioavailability of eicosapentaenoic acid from reconstituted triglyceride fish oil is higher than that obtained from the triglyceride and monoglyceride forms, Asia Pac. J. Clin. Nutr. 2010, 19, 499505.

37. G. Picotto, A. C. Liaudat, L. Bohl, N. Tolosa de Talamoni, Molecular Aspects of Vitamin D Anticancer Activity, Cancer Invest. 2012, 30, 604-614. https://doi.org/10.3109/07357907.2012.721039

38. Y.-N. Sheng, Y.-H. Luo, S.-B. Liu, W.-T. Xu, Y. Zhang, T. Zhang, H. Xue, W.-B. Zuo, Y.-N. Li, C.-Y. Wang, C.-H. Jin, Zeaxanthin Induces Apoptosis via ROSRegulated MAPK and AKT Signaling Pathway in Human Gastric Cancer Cells, Onco Targets Ther. 2020, 13, 10995-11006. https://dx.doi.org/10.2147/OTT.S272514 
Figure 1. Effects of fish oil, silica and FOS on cell viability /metabolic activity in NSCLC

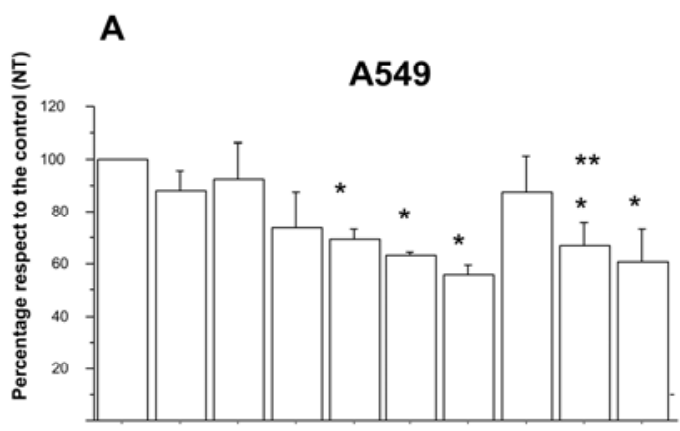

NT OIL 5 OIL 10 OIL 15 SIL 5 SIL 10 SIL 15 FOS 5 FOS 10 FOS 15

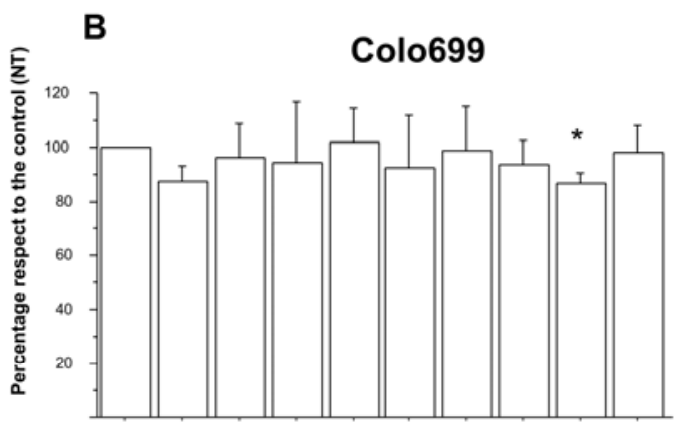

NT OIL 5 OIL 10 OLL 15 SIL 5 SIL 10 SIL 15 FOS 5 FOS 10 FOS 15

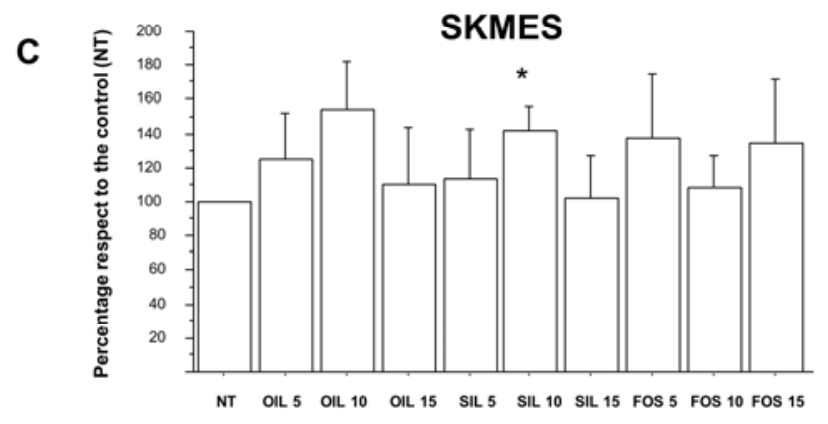


Figure 2. Effects of fish oil, silica and FOS in cell cycle events of A549

A

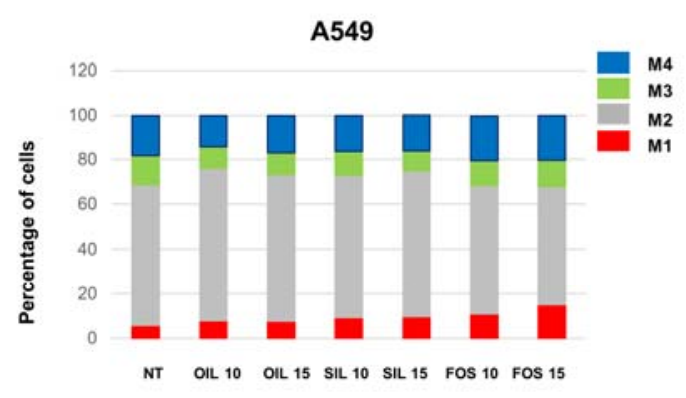

B

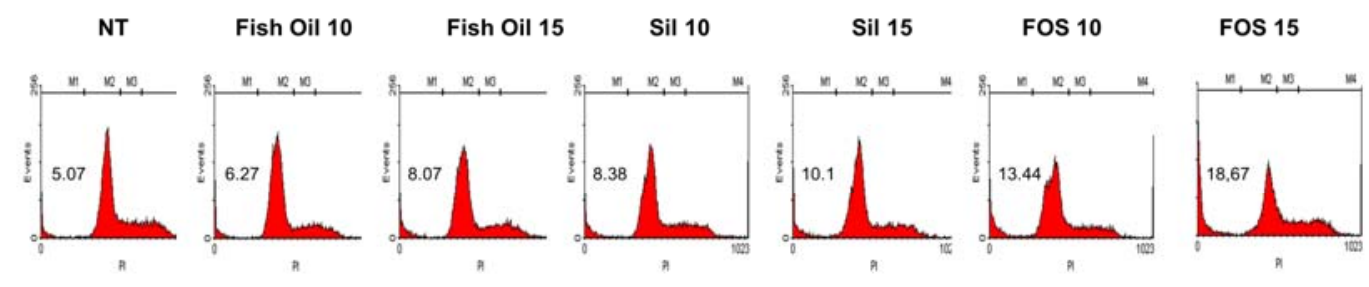

Figure 3. Effects of fish oil, silica and FOS in cell cycle events of COLO699

A
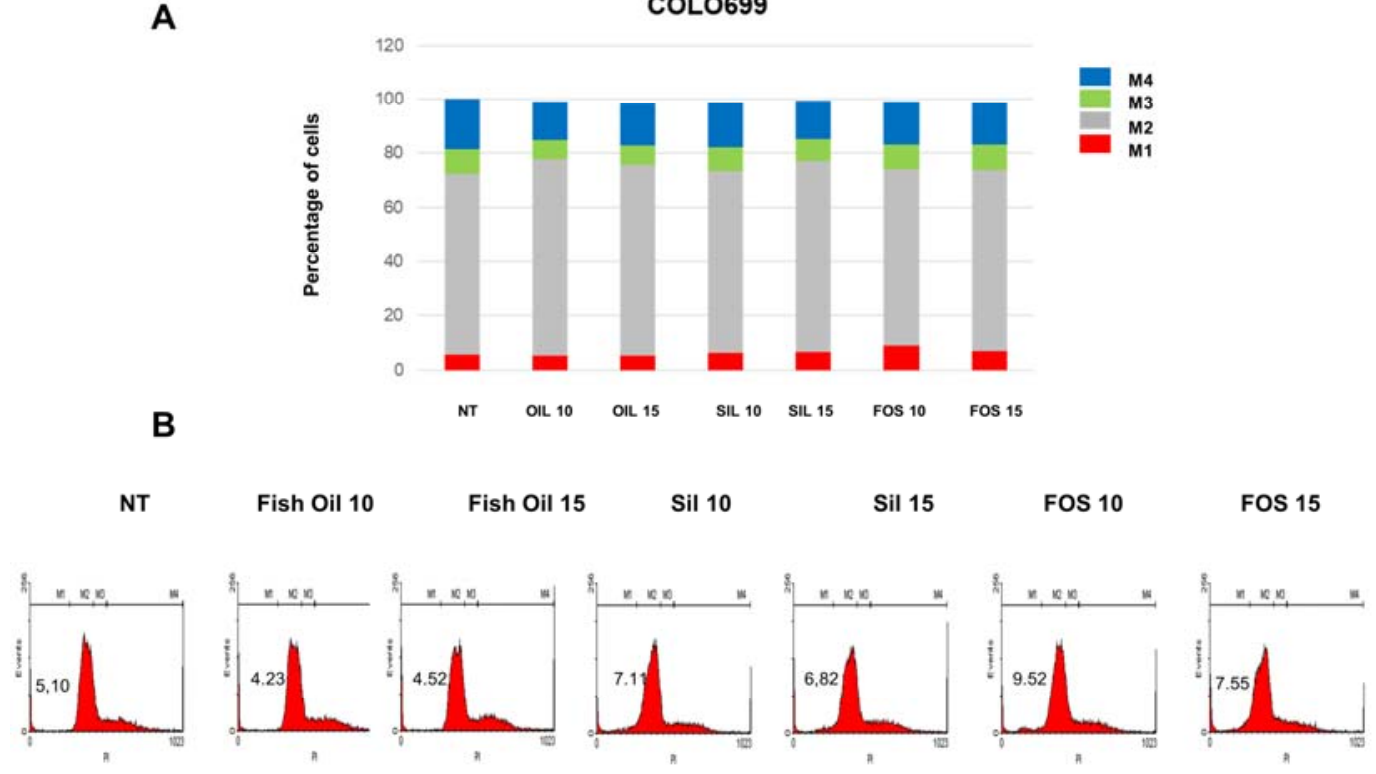
Figure 4. Effects of fish oil, silica and FOS in cell cycle events of SKMES

\section{SKMES}

A

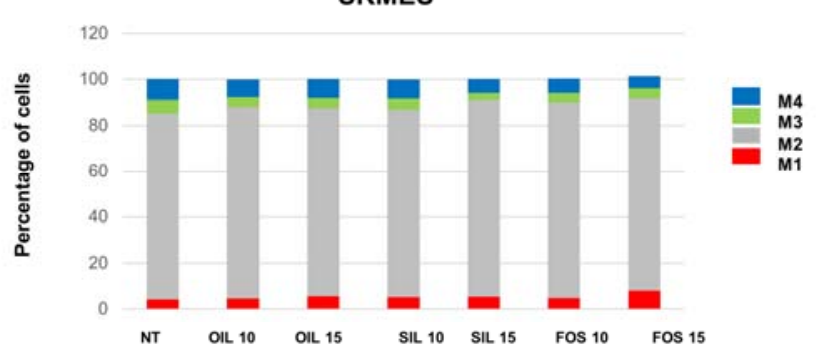

B

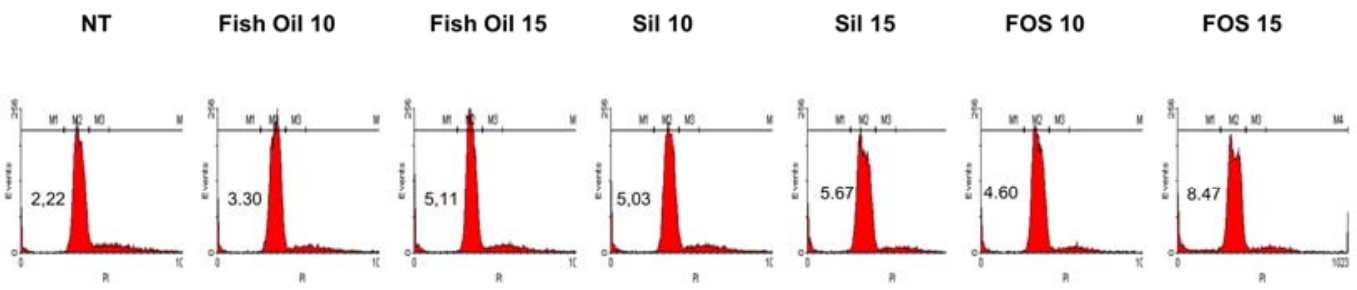

Figure 5. Effects of fish oil, silica and FOS in clongenic activity in NSCLC

A

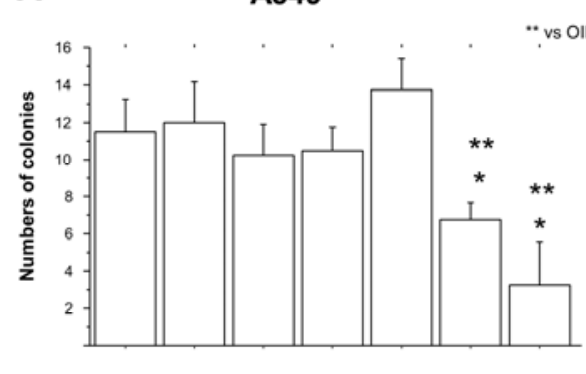

B Colo699

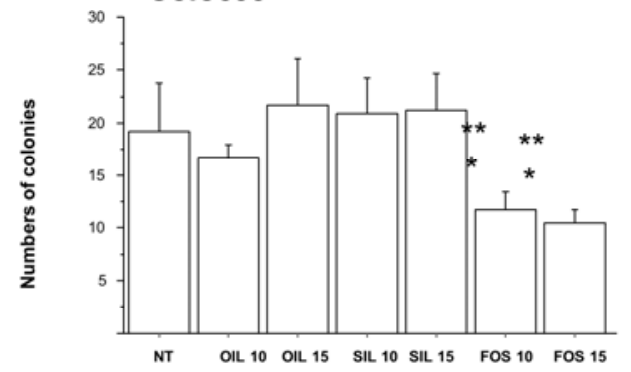

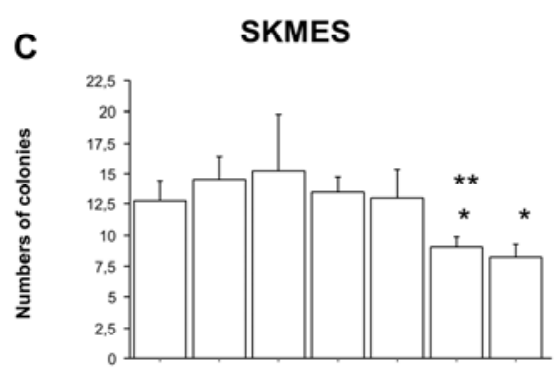

NT OIL 10 OIL 15 SIL 10 SIL 15 FOS 10 FOS 15 
Figure 6. Effects of fish oil, silica and FOS in mitochondrial superoxide production in A549

A

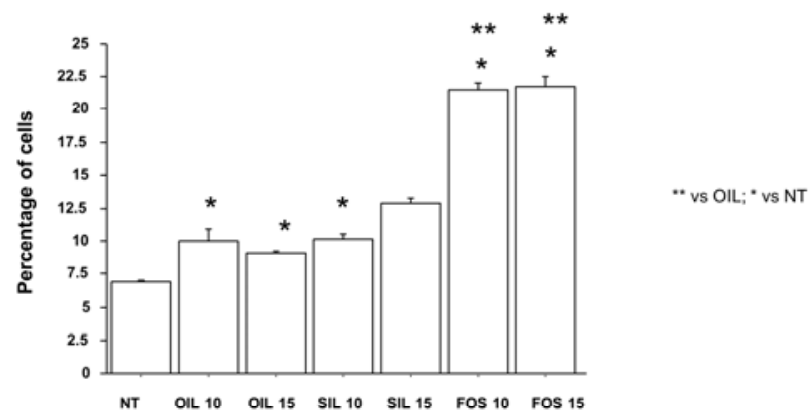

$\mathbf{B}$

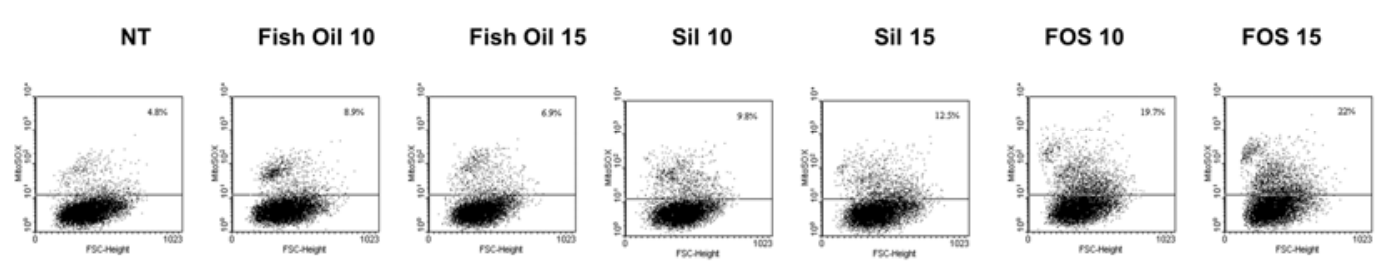


Figure 7. Effects of fish oil, silica and FOS in mitochondrial superoxide production in Colo699

A

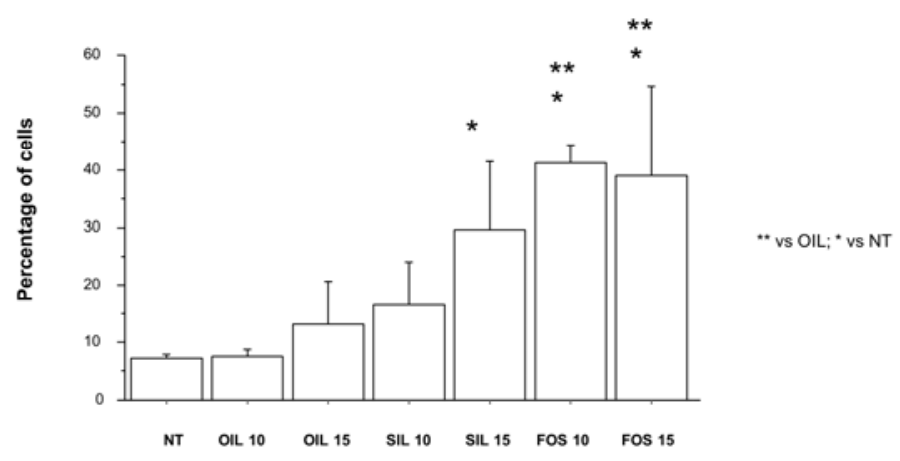

B

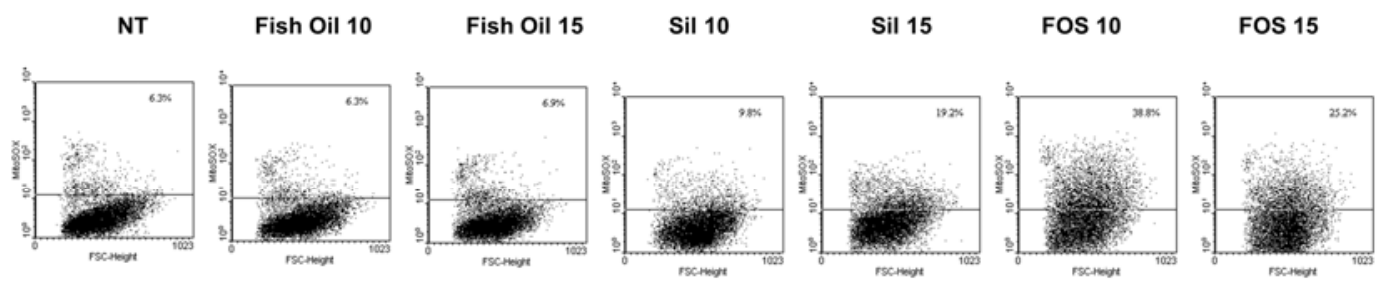

Figure 8. Effects of fish oil, silica and FOS in mitochondrial superoxide production in SKMES

A

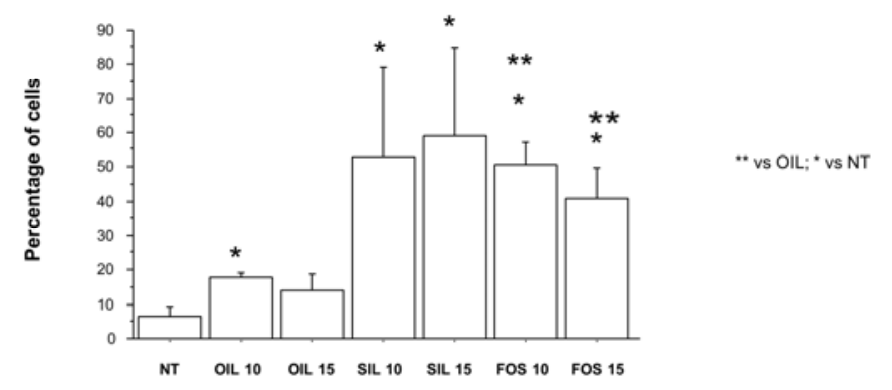

\section{B}

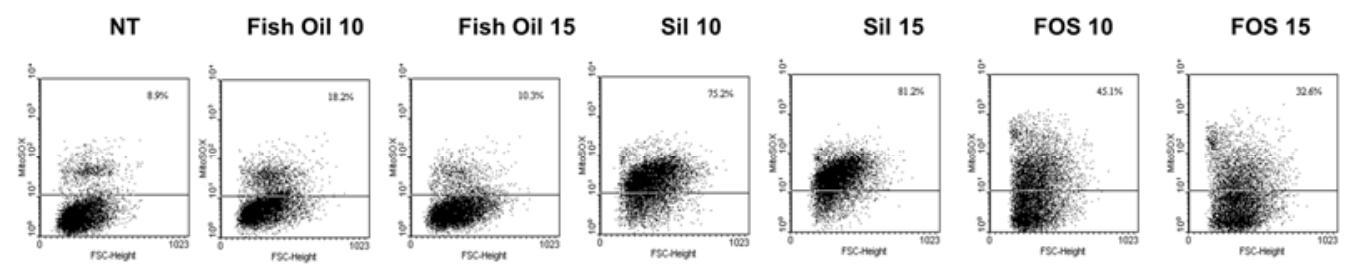


Figure 9. Effects of fish oil, silica and FOS in ROS production in A549

A

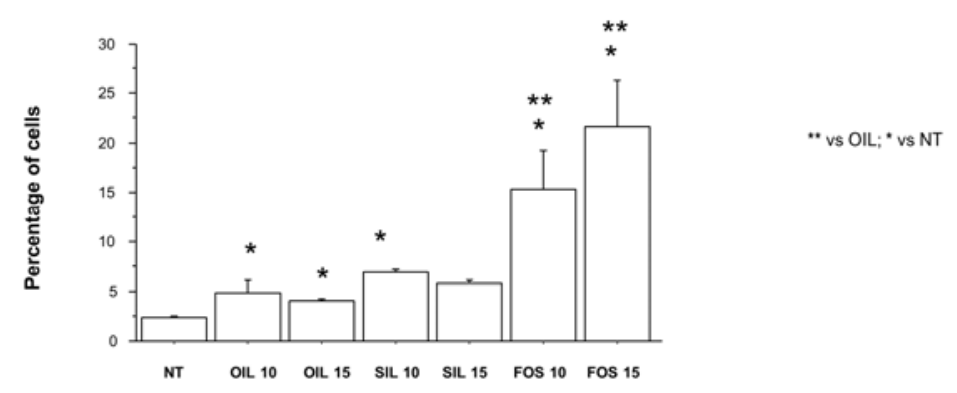

B

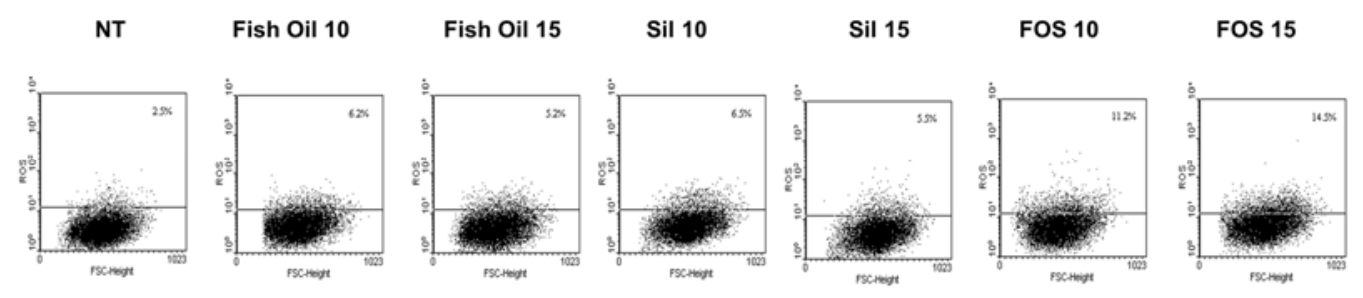

Figure 10. Effects of fish oil, silica and FOS in ROS production in Colo699

A

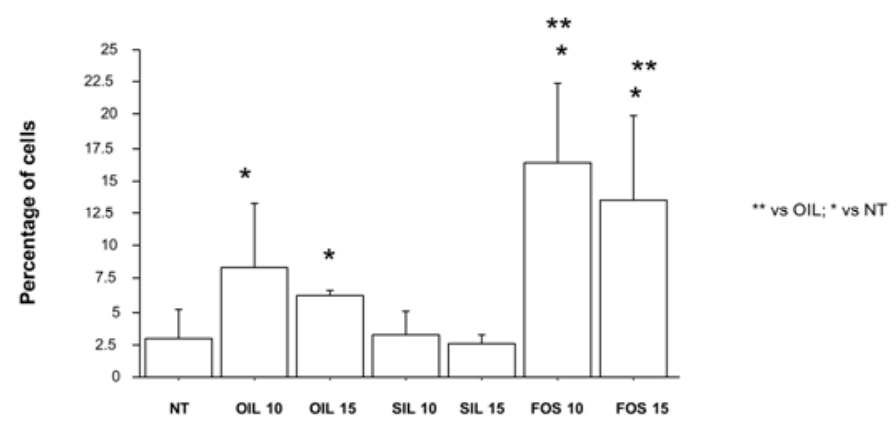

B

NT
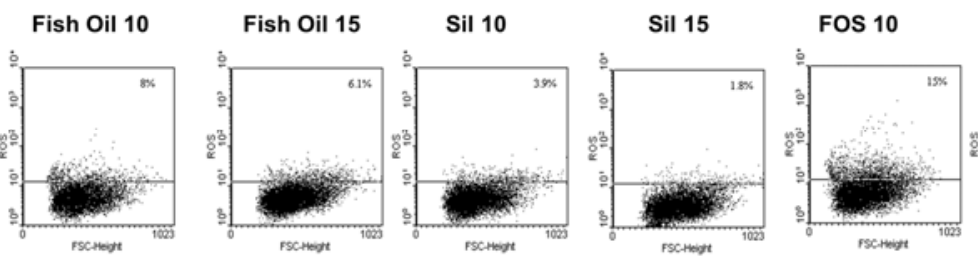

FOS 15
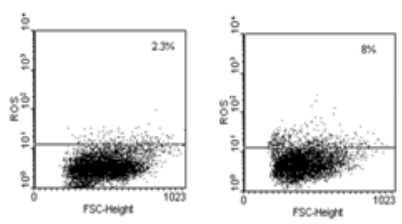

Pschojt

pscheopt

Pscitheyt

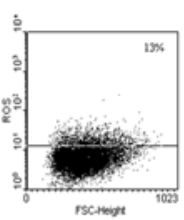


Figure 11. Effects of fish oil, silica and FOS in ROS production in SKMES

A

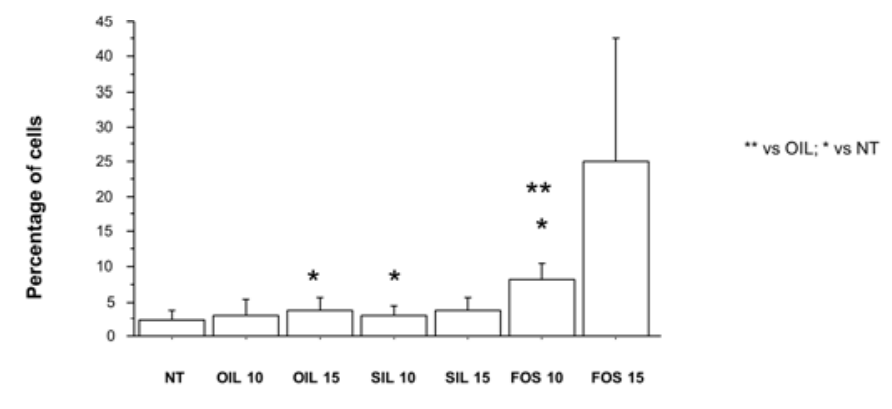

B

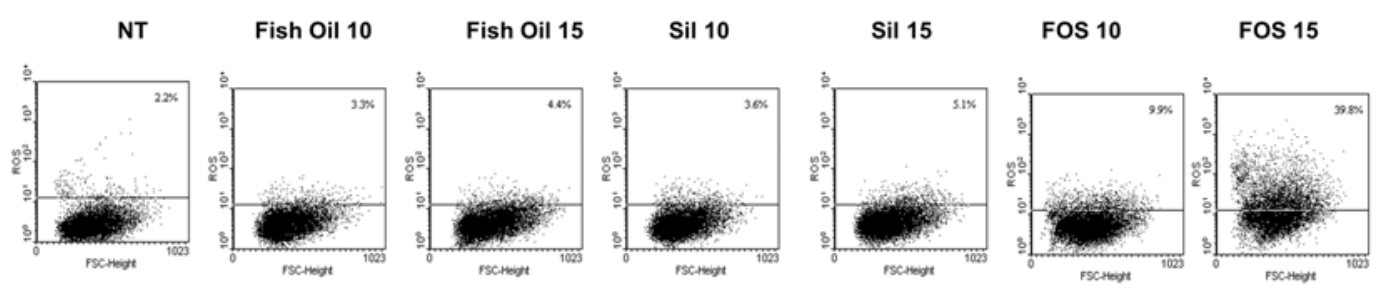


bioRxiv preprint doi: https://doi.org/10.1101/2021.04.20.440579; this version posted April 21, 2021. The copyright holder for this preprint (which was not certified by peer review) is the author/funder. All rights reserved. No reuse allowed without permission.
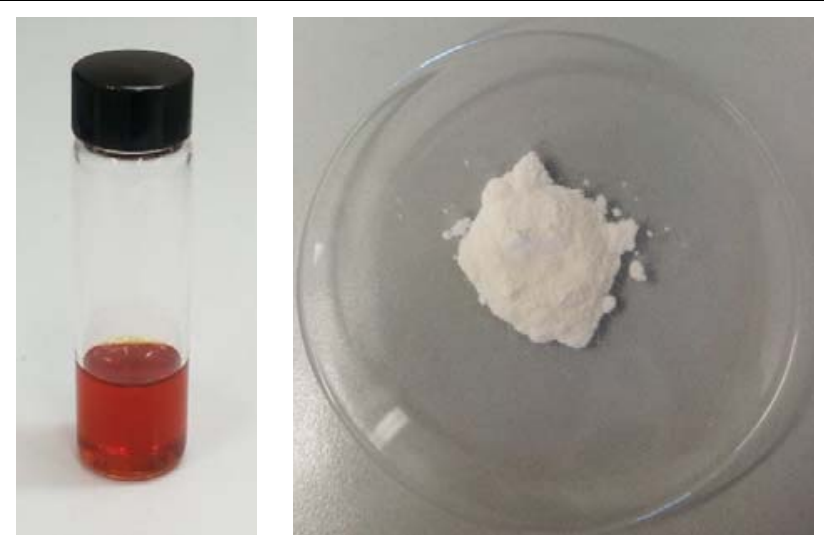

Figure S1. AnchoisOil extracted from anchovy filleting waste (left), Omeg@ Silica comprised of MCM-41 silica loaded with $50 \%$ w/w fish oil (right). 